DOI: 10.2478/v10122-010-0006-x

\title{
EVIDENTIALITY, INFERENTIALITY AND MIRATIVITY IN THE MODERN HINDI
}

\author{
ALEXANDER SIGORSKIY
}

\begin{abstract}
Aвstract. Alexander Sigorskiy. Evidentiality, Inferentiality and Mirativity in the Modern Hindi. Lingua Posnaniensis, vol. LII (1)/2010. The Poznań Society for the Advancement of the Arts and Sciences. PL ISSN 0079-4740, ISBN 978-83-7654-030-6, pp. 71-80

The questions of Evidentiality, Inferentiality and Mirativity in Hindi have not been thoroughly investigated so far. So the proposed description in no way can be exhaustive, and the results obtained are just preliminary. The approach adopted is functional, directed from function towards the modes of expression, because these categories in Hindi are rather semantic and functional, than structural and grammatical.

The results indicate that all the three domains are semantically close to each other. All of them denote a source of new information, but formally they are very different. Three kinds of Evidentiality - reported evidentials, inferred evidentials and miratives - represent a semantic field with fuzzy structure. The only grammaticalized types of evidentials are inferred evidentials marked by moods. All evidentials are combined with different modal meanings.

Some comparisons with other Indo-Aryan languages are made.
\end{abstract}

Alexander A. Sigorskiy, MGIMO University, Moscow, Russia

\section{INTRODUCTION}

1. Investigation of evidentiality in Hindi as well as in other Indo-Aryan languages is just in the initial stage. Nonetheless there are some important and informative papers available.

Peterson in his paper entitled "Evidentials, Inferentials and Mirativity in Nepali" ( $\mathrm{PE}-$ TERSON 2000: 13-36) describes evidentiality in Nepali as a part of the evidentiality system in the Himalayan area languages: "The pattern which has emerged is in essence the following: a single category usually serves to mark hearsay, inference through results, surprise and admiration" (PeTERSON 2000: 13). There are two perfects in Nepali - evidentiality unmarked and evidentiality marked which marks the mirative and inference through results. Inference from reasoning marks semantically presumptive future. Hearsay is marked by evidential marker re. In the second part of the paper "path of development" or the historical aspect of formation of evidentiality, including considerations about etymology of the particle re have been discussed. Obviously Nepali evidentials seem to be quite different from those in Hindi. 
BASHIR (2006: 30-50; 2009) explores evidentiality, indirectivity (inferentiality) and mirativity in old, middle and new Indo-Iranian languages including Dakhini Urdu, Hindi and Urdu. In Dakhini sarkaa "like" marks mirativity and inference from result, kaate "say" marks mirativity non-1st person, hearsay and traditional knowledge. In Hindi-Urdu mirativity is marked by the absence of the present AUX and by a simple, non-modified verb; hearsay is marked by sunaa "heard" and kahte haiN "they say"; inference through result by lagnaa "seem", "like" and traditional knowledge is marked by kahte haiN "they say" like hearsay (BASHIR 2006: 49).

Montaut (2001) compares evidentiality in Nepali and Hindi and argues the absence of the hearsay meaning in both of them. "These facts [...] question the common assumption that hearsay meaning is central to the notional category of evidentiality." In (MoNTAUT 2003: 345-364; and in MonTAuT 2006: 71-86) mirative extensions of aorist (preterit) are considered.

So the abovementioned authors distinguish three distinct domains in Hindi: evidentiality, inferentiality and mirativity, and admit their connection with perfective aspect and simple (non-modified, non-vector) verbs.

2. All of these three domains - reported evidentials, inferred evidentials, miratives (unexpected information) - share some common semantic properties: encoding or marking a new information source and its reliability. Structurally evidential utterance comprises two parts. The first one is a modal frame: as I infer (Inferentials), as I see (Mirativity), as I hear (Evidentials) (LAZARD 2001: 429). The modal frame or the modus includes also the speaker's assessment of the reliability of the information obtained. The second, following part of the utterance contains some new information obtained (see KozINTSEVA 2007: 15).

\section{INFERENTIALS}

The most grammaticalized domain of these three domains is inferentials comprised by the system of moods - future of indicative or presumtive, subjunctive and conditional. Inferentiality is not the only function of these moods, but obviously it is one of the main functions. Inferentials or inferred evidentials may be defined as follows: "Inferred evidential: information source based on conclusions drawn on the basis of what one can see, or the result of something happening" (AIKHENVALD 2004: 393).

\section{A GRAMMATICAL SKETCH OF THE HINDI MOODS}

Keeping Imperative aside the rest of the moods in Hindi are structured in a regular and symmetrical way. Each domain includes four verbal forms: one simple form and three analytical forms.

- Indicative Present

1. Simple form (imperfective participle) functioning as iterative or narrative and historical present. This form needs to be illustrated with an example: 


$$
\text { jab bhii aNdhii aatii, merii bahan ghabraajaatii }
$$
when ever storm .F.SG come. IMPF.F.S G $1^{\text {st }}$ POSS.F.SG sister.F.SG agitated go IMPF.F.SG 'Whenever it stormed, my sister would become agitated' (KACHRU 2006: 149, transliteration is mine $-A$.S., glosses are original).

2. Present (aataa hai "comes", kartaa hai "does").

3. Perfect (aayaa hai "has come", kiyaa hai "has done").

4. Present Continuous (a rahaa hai "is coming", kar rahaa hai "is doing").

- Indicative Past

1. Simple form (perfective participle) - Preterit is used sometimes as conditional. Example:

$$
\begin{array}{llll}
\begin{array}{l}
\text { agar naksaliyoN ne hamlaa kiyaa } \\
\text { if naxalites ERG }
\end{array} & \text { to vaayusenaa } & \text { bhii...kaarravaaii } \\
\text { karegii } & \text { take } & &
\end{array}
$$

If Naxalites would attack, then the Air Force will also take an action.(http:// www.bbc.co.uk/hindi/india/2009/10/091007_naxal_chidambaram_alk.shtml)

2. Imperfect (aataa thaa "came", kartaa thaa "did").

3. Pluperfect (aayaa thaa "had come", kiyaa thaa "had come").

4. Imperfect Continuous (a rahaa thaa "was coming", kar rahaa thaa "was doing").

- Indicative Future

There are two points of view about Future tense in Hindi, especially about analytical forms of Future. One of them argues that Future is a part of the Indicative mood; another one considers them as a system of the Presumptive mood. The argumentation against the Presumptive mood in favor of Future as a part of Indicative mood can be found in (LIPEROVSKIY 1964: 18-25; 1984: 124). The opposite point of view which accepts Presumptive mood as an independent mood in Hindi is presented for instance in (KACHRU 2006: 146).

1. Simple form (aaegaa "will come", karegaa "will do").

2. Future (Presumptive) imperfect (ataa hogaa "must be coming", kartaa hogaa "must be doing"').

3. Future (Presumptive) perfective (aayaa hogaa "would have come", kiyaa hogaa "would have done").

4. Future (Presumptive) Continuous (a raha hogaa "must be coming", kar rahaa hog$a a$ "must be doing").

- Subjunctive Mood

1. Simple Subjunctive (aae "may come", kare "may do"). As Old Present it is used in proverbs in its original function as Present:

$$
\begin{array}{lll}
\begin{array}{l}
\text { maar ke aaage bhuut } \\
\text { beating ahead } \\
\text { bhoot NOM M SG dances 3SG }
\end{array} \\
\text { (Even) bhoot (ghosts) dances in the face of beating (ZOGRAF 1998: 215). }
\end{array}
$$


2. Subjunctive imperfective (aataa ho "may come", kartaa ho "may do").

3. Subjunctive Perfective (aayaa ho "would / might have come"; kiyaa ho "would / might have done").

4. Subjunctive Continuous (a rahaa ho "would be coming", kar rahaa ho "would be doing").

- Conditional Mood

1. Simple Form (aataa "were he to come", kartaa "were he to do").

2. Conditional Imperfective (ataa hotaa "were I came", kartaa hotaa "were I done").

3. Conditional Perfective (ayaa hotaa "had I came", kiyaa hotaa "had I done").

4. Conditional Continuous (a rahaa hotaa "were he be coming", kar rahaa hota "were he be doing").

All simple finite verbal forms tend to express indirect modality. Imperfect and Perfect Participles besides their primary function as markers of imperfect and perfect aspect are markers of conditional or counterfactual (unreal) modality. Simple future, especially of honaa "to be" verb, marks presumptive modality; and simple subjunctive marks hypothetical modality. All of them retain to some extent their original direct modal semantics.

The four moods represent a scale of modalities: indicative (indicative mood), presumptive (future forms of the indicative), hypothetical (subjunctive mood) and counterfactual (conditional or unreal mood).

Now a set of examples is given to illustrate interaction of inferentials with modality marked by different moods, or in a wider sense, their interplay with TAM - tense, aspect, mood; the interplay between inferred evidentials with modal frame representing a degree of reliability from the point of view of the speaker who is the author of the utterance.

- Indicative Present and Present Continious

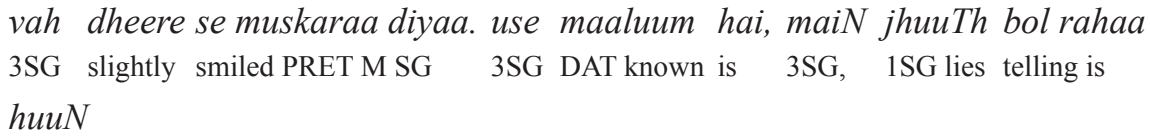

He gently smiled. He knows I am lying (VARMA 1989: 82).

The speaker has read the smile of his friend as a hint that the latter has understood that the speaker is telling a lie and the speaker is sure about it. Here the Indicative mood marks this sureness of the speaker.

- Indicative Future

$$
\begin{aligned}
& \text { maiNne socaa thaa, acaanak use dubaaraa dekhakar vah } \\
& \text { 1SG ERG thought was M SG PIPerf suddenly 3SG DAT again seen CONV 3SG NOM } \\
& \text { aašcaarya meN paR jaayegii } \\
& \text { surprise in LOC fall will FUT F SG } \\
& \text { I thought she will be surprised seeing him again (ibid.: 99). }
\end{aligned}
$$


The speaker has inferred what will be in a few moments. Presumptive future refers to subsequent point of time in the past (Future in the past).

- Presumptive future imperfect

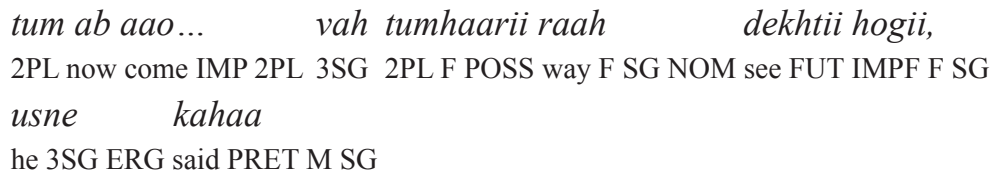

The speaker has inferred a situation which is quiet possible at this point of time (simultaneous with the point of reference).

- Presumptive future perfect

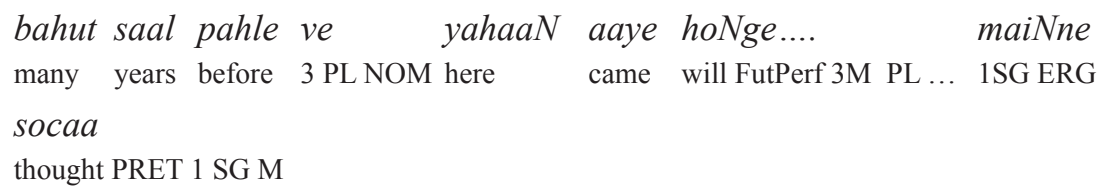

They may have come here many years ago, I thought (ibid.: 99).

- Subjunctive perfect

$\begin{array}{lll}\begin{array}{l}\text { Sambhav hai, } \\ \text { maybe AUX 3 SG PRES 1SG ERG 2 PL DAT }\end{array} & \text { kahiiN saRak par dekhaa ho, } \\ \text { usne } & \text { haNste hue } & \text { kahaa } \\ \text { 3 SG ERG } & \text { laughing CONV } & \text { said PRET M SG }\end{array}$

I may have seen you somewhere on the street; she said laughing (ibid.: 176).

Examples (8) and (9) demonstrate a contrast between presumptive and hypothetical modality marked by presumptive future and subjunctive, respectively. Presumptive indicates that the speaker is more convinced about his assumption while hypothetical subjunctive indicates that the speaker is less convinced about his assumption, and consequently the information obtained is less reliable.

Some lexical entries modify modal meaning of the verbal phrase. Thus shaayad hii "hardly" indicates that an assumption is highly improbable. So hypothetical modality turns to dubitative (but not unreal).

šaayad hii kabhii kisii ne naNge sir dekhaa ho appaa saahab ko Hardly once somebody ERG bare head has seen PerfSubj 3 M SG appa sahib ACC sp Hardly one ever has seen Appa Sahab bare headed

(BHANDARi 1989: 48).

- Simple conditional

$$
\text { Raayanaa use dekhtii to ava ̌̌ya cakit rahjaatii }
$$

Rayana F SG NOM 3 SG ACCsp see COND F SG certainly surprised would be COND F SG Had Reina seen him she might have been certainly surprised 
The speaker presupposed a situation that can not become real and speculates about what might happen if inferred presupposition would have taken place.

Aikhenvald argues "that irrealis and information source are different categories" (AikHENvald 2004: 257). But material of Hindi demonstrates that, first, inferred evidentials and epistemic modality (presumptive, hypothetical and counterfactual) are combined in one and the same grammatical form - moods, and second, new information is represented in inferred evidentials in a wider sense - as "world-building" or "construction of new worlds".

- Conditional Perfect

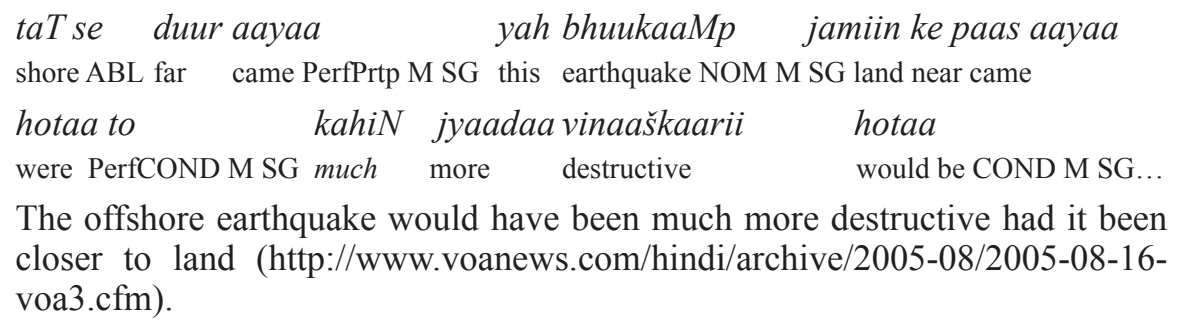

\section{MIRATIVITY}

Mirativity reports "information which is new or surprising to the speaker regardless of whether the information source is first- or second-hand" (DELANCEY 1997: 33)". "Mirativity covers speaker's 'unprepared mind', unexpected new information, and concomitant surprise" (AiKHENVALD 2004: 196).

- Mirativity mainly is marked in Hindi by different types of exclamatory sentences.

Exclamatory sentences with exclamatory particles:

Baap re baap! Yah kyaa hai?

Daddy, oh daddy! This what is $3 \mathrm{SG}$ ?

Oh, my God! What is it?

(http://akhirikalam.bharatuday.in/2007/05/blog-post_10.html)

Preterit (aorist)-marked Miratives with inversion involved:

sipaahii kaa beTaa niklaa cor, tiin giraftaar

policeman GEN M SG son M SG turned out PRET M SG thief, three arrested

The son of a policeman turned out to be a thief, three are arrested (4 Apr 2009, 0130 hrs IST, http://navbharattimes.indiatimes.com/articleshow/4356406.cms)

- Miratives with different verbal forms:

Perfect

Dekh rahaa huuN hamaarii kal kii nanhiiN guRiyaa aaj dekhte

(I) see PrCont 1M SG our F SG GEN yesterday's small F SG doll F SG today 
dekhte kitnii baRii ho gayii hai

seeing seeing CONV how F SG big F SG become has PERF F SG

I wonder our little doll has grown so fast before our own eyes (08.25.2007, http://www.sahityakunj.net/LEKHAK/P/Parashargaud/adhure_sapne1.htm)

Present Continuous
Are, tuu to bahut jaldii-jaldii baRii ho rahii hai, sonaa!
Really, you 1 SG very quickly tall F SG growing is PrCont F SG, Sona!
Really, you are growing tall very quickly, Sona!

(BHANDARI 1989: 50).

- Syntactic type of Mirativity:

Mirativity can be expressed by a syntactic construction referred as "double predicate construction" (CHERnYSHEv 1968), "Theme-Focussing" (GAMBHIR 1983), or "thematic jo hai vo construction" (DAVISON 2007: 236). But mirative reading of this construction seems to be context-bound.

$$
\begin{aligned}
& \text { par locan baabuu haiN ki na mantrimaNDal kii mRtyu kii } \\
& \text { but Lochan Babu are 3PLHON that neither cabinet of ministers GEN F SG death GEN F SG } \\
& \text { ghoŞNaa se pulkit ho rahe haiN, na raav-caudhrii kii kiimat se camatkRt } \\
& \text { news by happy are PrCont3PL HON, nor rao-caudhri GEN F SG price by surprised }
\end{aligned}
$$

But as for Lochan Babu he is not happy neither about announcement of the fall of the cabinet of ministers, nor is not surprised by the value of Rao-Chaudhri (BHANDARI 1989: 58).

This construction reports surprise of the speaker at somebody's reaction towards some event.

Mirativity can be expressed in the same way as inferred evidentiality - by moods.

$$
\begin{array}{ll}
\text { biyar kaa DeRh gilaas } & \text { piine ke baad raayanaa itne khule, } \\
\text { Beer GEN M SG one and a half glass ACCunsp } & \text { drink after Reina F SG so free } \\
\text { sahaj bhaav se bolne lagegii } & \text { maiNne nahiiN socaa thaa } \\
\text { and easy } \quad \text { talk will begin FUT F SG } & \text { 1SG ERG no thought was PIPerf M SG }
\end{array}
$$

I had not thought that Reina would begin to talk so freely and easyly after taking one and a half glass of beer (VARMA 1989: 98).

\section{EVIDENTIALITY}

According to Aikhenvald, "All evidentiality does is supply the information source. The ways in which information is acquired - by seeing, hearing, or in any other way - is its core meaning" (AIKHENVALD 2004: 4).

From examples given below we can see that Hindi seems to lack pure category of evidentiality as well as other related categories of inferentiality and mirativity. A report about new information usually is combined with its estimation, or/and reaction of a (the) speaker. 
Usne bataayaa ki sunaahai ki tumhaare mohallevaale

3SG ERG told PRET M SG that heard is PERF M SG that yourPOSS 2PL localityM SG avinaaš ko roj caar Daalar milne lage haiN, pemeNT guugal vaale avinaš DAT daily 4 dollars M PL get began PERF M PL payment Google's people kar rahe haiN. maiN ne kahaa ki mujhe to koii jaankaarii nahiiN is doing PrCont M PL1SG ERG told PRET M SG that me DAT any information no

He told that he has heard that Avinash from our locality has started getting four Dollars per day; payment is made by Google's people. I told that I know nothing about it (http://taanabaana.blogspot.com/2008/02/blog-post_13.html)

$\begin{array}{ll}\text { jahaaN tak mujhe maaluum hai aThaarahviiN } & \text { śataabdii se pahle hinduu vahii } \\ \text { As far as me DAT know } & 18^{\text {th }} \text { century }\end{array}$ ho saktaa thaa joki paidaa hii hinduu huaa ho. Yah niyam could PIPerf M SG who bourn Hindu M SG would be SubjPerf M SG. This rool ACCunsp M SG kisne badlaa yaad nahiiN who ERG changed PRET M SG memory not

As far as I know, before $18^{\text {th }}$ century a Hindu can be only the one who was borne a Hindu. Who has changed this rule I don't remember (http://halchal.gyandutt. com/2008/11/blog-post_25.html).

Converb of the verb kahnaa "to say" functions as a quotative in Hindi:

khair choRiyesar kahkar usne aaNsuu poNche...

All right, give it up, sir, having said CONV 3 SG ERG tears M PL wiped PRET M PL

All right, stop it, sir, she said and wiped her tears

(Sunday 20 Sep, 2009 01:55 PM, http://www.pressnote.in/readnews. php?id=52348)

Grammaticalized quotatives are represented in Dakhini Hindi (KACHRU 1986: 166-167) and in other old, middle and new Indo-Aryan languages (MeEnakshi 1986; SingH 1980). Comparison of quotatives in Hindi and Russian is made in (SigORSKIY 2006: 142-144).

Reported evidentials indicate the information a speaker is not sure about, the information which is unreliable and doubtful from the point of view of the speaker.

\section{CONCLUSION REMARKS}

Summarizing my preliminary results I may conclude that all the three domains - evidentials, inferentials and miratives - comprise one category which denotes a source of new information. Information may be reported, inferred or be unexpected for the speaker. My conclusion agree with those of G. Lazard who has combined them into a category of mediativity (LAZARD 1999; 2001). This category mainly is not grammatical, but functional and semantic with fuzzy field structure. They are what (AIKHENVALD 2004: 392) calls evidential extensions or strategies: "use of a non-evidential category (such as tense, aspect, or modality) to refer to an information source". Evidentiality uses mainly narrative or descriptive strategies; mirativity employs syntactic strategies; while inferentials are grammaticalized 
modes of expression. "Pure" evidentiality is not observed in Hindi. Everywhere it is combined with some modal semantics denoting various degrees of reliability of the information concerned.

\section{ACKNOWLEDGMENTS}

I am very grateful to Prashant Tripathi and Hem Chandra Pande for corrections and valuable and helpful comments.

\section{SYMBOLS}

ACC - accusative

ACCsp - accusative specific

ACCunsp - accusative unspecific

AUX - auxiliary

COND - conditional mood

CONV - converb

DAT - dative

ERG - ergative

$\mathrm{F}$ - feminine

FUT - future

FutPerf - Future Perfect

GEN - genitive

$\mathrm{HON}$ - honorific

IMP - Imperative

IMPF - imperfect

LOC - locative

\author{
$\mathrm{M}$ - masculine \\ $\mathrm{NOM}$ - nominative \\ PERF - perfect \\ PerfCOND - Perfect Conditional \\ PerfPrtp - Perfective Participle \\ PerfSubj - Perfect Subjunctive \\ $\mathrm{PL}$ - plural \\ PlPerf - Pluperfect \\ POSS - possessive \\ PrCont - Present Continuous \\ PRES - Present \\ PRET - preterit \\ $\mathrm{SG}$ - singular \\ SUBJ - subjunctive \\ SubjPerf - subjunctive perfect
}

\section{PRIMARY SOURCES}

Mannu Bhandari. 1989 (1 $1^{\text {st }}$ ed. 1979). Mahabhoj (The Great Feast). Dilli: RadhaKrishna.

VARMA Nirmal. 1989 (1 $1^{\text {st }}$ ed.1964). Ve din (Those Days). Nai Dilli: Rajkamal Prakashan.

\section{REFERENCES}

Aikhenvald Alexandray. 2004. Evidentiality. New York: Oxford University Press.

Barkhudarov Aleksey S., Beskrovnyy Vasiliy M., Zograf Georgiy A. 1998. Poslovitsy i pogovorki Severnoy Indii. Sankt-Peterburg: Tsentr "Peterburgskoye vostokovedeniye."

BASHIR Elena. 2007. "Evidentiality in South Asian Languages." The Proceedings of the LFG-06 Conference, 30-50. http://cslipublications.stanford.edu/LFG/11/lfg06.html.

BASHIR Elena. 2009. "Traces of Mirativity in Shina." South Asian Languages Analysis 2009 (SALA XXVIII), Abstracts. www.sala.unt.edu/SALA_2009_Abstracts.pdf.

Beskrovnyy Vasiliy M., Bykova Elena M., Liperovskiy Vladimir P. (eds.). 1968. Yazyki Indii, Pakistana, Nepala i Tseilona. Moskva: Nauka, Glavnaya redaktsiya vostochnoy literatury.

Chernyshev Vladimir A. 1968. "Ob odnom priyeme stilisticheskogo sintaksisa khindi (dvoinoye skazuyemoye)" [Concerning One Method of Stylistic Syntax of Hindi (Double Predicate)]. In: Beskrovnyy et al. 1968: $252-259$. 
DAvison Alice. 2007. "Hierarchical Structure and Linear Order: Correlative Clauses in Hindi-Urdu." In: MasicA 2007, 211-245.

DeLAnCEY Scott. 1997. "Mirativity: The Grammatical Marking of Unexpected Information.” Linguistic Typology $1,33-52$.

GAMBHIR Vijay. 1983. "Theme-Focussing in Hindi." Indian Linguistics 44, 1-4, $25-38$.

Kachru Yamuna. 1986. "The Syntax of Dakkhini: A Study in Language Variation and Language Change." In: KRISHNAMURTI et al. 1986: 165-174.

KACHRU Yamuna. 2006. Hindi. Amsterdam-Philadelphia: John Benjamins.

KHRAKovskiY Viktor (ed.). 2007. Evidentcial'nos't v yazykakh Evropy i Azii. Sankt-Peterburg: Nauka.

KozinTSEva Nataliya M. 2007. “Tipologiya kategorii zasvidel'stvovannosti” [Typology of the Category of Evidentiality]. In: KHRAKOvSKIY 2007, 13-26.

Krishnamurti Bh., Masica Colin P., Sinha Anjali K. (eds.). 1986. South Asian Languages: Structure, Convergence and Diglossia. Delhi: Motilal Banarsidass.

LAZARD Gilbert. 1999. “Mirativity, Evidentiality, Mediativity, or other?” Linguistic Typology 3(1), 91-109.

LAZARD Gilbert. 2001. Études de linguistique générale. Typologie grammaticale. Leuven-Paris: Peeters, 425441.

LIPEROVSKIY Vladimir P. 1964. Kategoriya nakloneniya v sovremennom literaturnom khindi [Category of Mood in Modern Literary Hindi]. Moskva: Nauka.

LiPEROVSKIY Vladimir P. 1984. Glagol v yazyke khindi [Verb in the Hindi Language]. Moskva: Nauka.

LönNE Dirk W. (ed.). 2003. Tohfa-e-dil, Festschrift Helmut Nespital. Reinbek: Dr. Inge Wezler Verlag fur Orientalische Fachpublikation, 1.

Masica Colin P. (ed.). 2007. Old and New Perspectives on South Asian Languages: Grammar and Semantics. Delhi: Motilal Banarsidass Publishers.

MeEnAKshi K. 1986. “The Quotative in Indo-Aryan.” In: Krishnamurti et al. 1986: 209-218.

Montaut Annie. 2001. "Evidentiality in Indo-Aryan: the Absence of the Hearsay Meaning and the Delimitation of the Category Evidentiality." http://ling.uni-konstanz.de/pages/conferences/sala01/abstracts.

Montaut Annie. 2003. "On the Evidential Meanings of the Hindi Aorist." In: LönNe 2003: 345-364.

Montaut Annie. 2006. "Mirative Meanings as Extensions of Aorist in Hindi/Urdu." In: Singh 2006: 71-86.

Peterson John. 2000. "Evidentials, Inferentials and Mirativity in Nepali." Linguistics in the Tibetan-Burman Area 23(2), 13-36.

SigorsKiY Alexander A. 2006. "Khindi i russkiy: nekotoryye aspekty grammatiki i funktsionorovaniya" [Hindi and Russian: Some Aspects of Grammar and Functioning]. In: Vedenina 2006: 138-151.

Singh Rajendra (ed.). 2006. The Yearbook of South Asian Languages and Linguistics 2006. Berlin-New York: Mouton de Gruyter.

Singh Udaya Narayan. 1980. “Bole: An Unresolved Problem in Bengali Syntax.” Indian Linguistics 41(1), 188195.

Vedenina L'udmila G. (ed). 2006. Lingvostranovedeniye: metody analiza, tekhnologiya obucheniya, 1. Moskva: MGIMO-Universitet.

ZoGraF Georgiy A. 1998. "O yazyke poslovits" [About the Language of Proverbs]. In: BARKHUdARov et al. 1998: 213-215. 